\title{
UNIVERSITYOF
}

FORWARD

THINKING

WESTMINSTER用

WestminsterResearch

http://www.westminster.ac.uk/westminsterresearch

Urban tourism as a bone of contention. Four explanatory

hypotheses and a caveat

Novy, J.

This article is ( ) Emerald and permission has been granted for this version to appear here: http://westminsterresearch.wmin.ac.uk/21215/

Emerald does not grant permission for this article to be further copied/distributed or hosted elsewhere without the express permission from Emerald Group Publishing Limited.

The final, published version in International Journal of Tourism Cities, doi: 10.1108/IJTC01-2018-0011, 2018 is available at:

https://dx.doi.org/10.1108/IJTC-01-2018-0011

The WestminsterResearch online digital archive at the University of Westminster aims to make the research output of the University available to a wider audience. Copyright and Moral Rights remain with the authors and/or copyright owners.

Whilst further distribution of specific materials from within this archive is forbidden, you may freely distribute the URL of WestminsterResearch: ((http://westminsterresearch.wmin.ac.uk/)).

In case of abuse or copyright appearing without permission e-mail repository@westminster.ac.uk 


\title{
Urban tourism as a bone of contention. Four explanatory hypotheses and a caveat
}

\author{
Johannes Novy \\ Faculty of Architecture and the Built Environment \\ Westminster University \\ 35 Marylebone Road \\ London NW1 5LS \\ j.novy@westminster.ac.uk
}




\section{Urban tourism as a bone of contention. Four explanatory hypotheses and a caveat $^{*}$}

\section{Introduction}

For anyone with the slightest interest in tourism in cities and the politics thereof, recent years were, by all means, exciting times. Coincidentally around the same time that the tourism sector celebrated the symbolic milestone of more than one billion annual international tourists (UNWTO, 2012), an upsurge of debates and controversies surrounding tourism in cities became increasingly difficult to ignore. These debates and controversies were triggered by an observable spread of manifestations of protest and resistance in some cities, most notably Barcelona and Venice, as well as evidence of growing discontent and concern over tourism in several others, including Amsterdam, Berlin, and Lisbon to name but a few. Whether or not it is reasonable to speak of a 'revolt against tourism', as some have done (Becker, 2015), is debatable but what seems clear is that tourism, hitherto in most contexts rather a non- or minor issue in urban politics and struggles, has in a variety of contexts become increasingly problematised and politicised (Novy and Colomb, 2016).

Elsewhere, I have cautioned against generalising about the causes and characteristics of this problematisation and politicisation (Novy and Colomb, 2016; Novy, 2017). Conflicts surrounding tourism have been studied extensively in other than urban settings but not so much in cities and particularly research that extends beyond case studies is rare. As a result, we know relatively little about the precise nature and sources of the recent wave of conflicts and contestations and neither do we know much about the way developments in different contexts

\footnotetext{
* Acknowledgements: This commentary draws both from the presentations and discussions with conference participants at the seminar "Réinventer l'ordinaire : les fronts pionniers du tourisme. Lieux, acteurs, imaginaires" ar EIREST, Université Paris 1 Panthéon-Sorbonne, on February 2, 2017 and the International Symposium "Reshaping European cities? - Exploring policies, practices and everyday realities concerning 'Airbnbification" at the University of Salzburg on November 25, 2017. Special acknowledgements also go to the anonymous reviewers for their valuable comments and directions to improve the quality of the paper.
} 
compare to one another. In addition, one ought to be careful to keep things in perspective: it is still a relatively small number of cases that dominate the debate surrounding urban tourism as a source of contention and dispute. In the overwhelming majority of cities conflicts surrounding tourism appear to this day not to be much of an issue or no issue at all.

What is more is that conflicts about and around tourism in cities are by no means altogether new. With the exception of long-standing tourist cities such as Venice organised protests have until recently been extremely rare to be sure, but conflicts don't necessarily have to manifest themselves in the form of collective social mobilizations. Instead, discontent with and resistance to the presence and impacts of tourism flows can also express themselves in multiple other ways. These range from 'covert resistance' such as the avoidance of tourist hotspots to the use of parody and subversion and such strategies have certainly not been unheard of in the past (Boissevain, 1996; see also Gravari-Barbas and Jacquot, 2016).

Significantly, however, all of this does not make it any less relevant to deal with the recent developments that have transformed what once was a marginal topic into a focal point of discussion in the media and beyond. ${ }^{1}$ Making no attempt at being comprehensive or representing the full range of scholarly debate and drawing on a mix of empirical and conceptual findings in the literature, the following pages will, therefore, introduce a couple of observations regarding the rise of conflicts and disputes surrounding urban tourism, the debates they have sparked, and the scholarly engagement with them so far. Among the issues the commentary will address are (i) the role of urban tourism's massive and often rapid growth; (ii) the fact that backlashes in cities are often less directed against tourism in its entirety than against particular kinds of tourism (or tourists); (iii) the need to look at contestations surrounding urban tourism not in isolation from, but in firm connection with the wider social and political contexts in which they occur; (iv) the extent to which contestations are fuelled by broader spatial restructuring processes such as gentrification as well as the ongoing, and, it seems, accelerating, geographical spread of tourism; and, lastly, (v) the need to critically engage with the notion of tourism itself and move beyond essentialising narratives that portray tourism as an alltogether distinct, easily separable social phenomenon.

\footnotetext{
${ }^{1}$ For some examples of the extensive media coverage see Devaney, 2015; Becker, 2015; and Coldwell, 2017.
} 


\section{The growing pains of rapid growth}

What explains the rise of contestations surrounding tourism? There is no simple answer to this question; but a large part of the answer, I believe, can be summed up in a short phrase: with rapid growth comes growing pain. Urban tourism generally has, as is well known, grown significantly in recent decades (IPK, 2016) and several of the cities in which conflicts have occurred have experienced particularly sharp rises in tourism from often already high levels.

Barcelona is a case in point: between 2000 and 2016 the number of visitors staying overnight in official accommodation increased by a whooping 188 percent from 3.1 to more than 9 million guests. In Berlin the picture is similar - the number of overnight guests in Germany's capital staying in official accommodation increased by more than 154 percent from 5 million to 11.4 million in the same period while Amsterdam saw the number of hotel and hostel guests increase by 80 percent from 4 million in 2000 to more than 7.2 million in 2016 (TourMIS, 2017). These figures are all the more impressive against the backdrop of the parallel rise of the (corporate-led) sharing or platform economy whose share of the overall accommodation market has vastly increased in recent years. Add to this the considerable growth of the day-trip market in these cities (and in cities in general) as well as the growing problems with overcrowding - of tourist sites, public spaces and transport services - some of them are confronted with, and it becomes understandable why there is increasing talk about tourism demand exceeding desirable limits in some cities.

In fact, there is even a new word making the rounds to describe the potential problem of too many tourists in cities, 'overtourism' (Sheivachman, 2017; Goodwin, 2017). Concerns about the latter are particularly widespread in Barcelona - its recently adopted tourism plan Pla Estratègic de Turisme 2020 identifies 'problems of saturation and over-exploitation' as a key challenge the city finds itself confronted with (Ajuntament de Barcelona, 2017). But they resonate in other cities too. In Amsterdam, where the growth of tourism is, as Pinkster and Botermann $(2017,458)$ observe 'fast becoming one of the most debated and contentious issues in the city', the city's former mayor, Eberhard van der Laan, caused a stir in 2016 by contemplating the idea that there 
is a limit to the city's hospitality. In a widely noted speech, he acknowledged the manifold pressures tourism exerts on parts of the city and expressed concern about what might lie ahead: 'There are 300 million people from China and India getting ready to travel the world,' he noted. 'We are in a hurry to do something' (cited in Slegers, 2017). This sentiment also seems to be echoed by a growing number of industry stakeholders, as was evident at the 2017 World Travel Monitor Forum in Pisa where 'overtourism' was a much-discussed concern (ITB Berlin, 2017). They recognise that problems resulting from excessive visitor numbers not only affect those being visited but also those doing the visiting: in cities such as Amsterdam and Barcelona up to one in five tourists experienced their visit according to survey data released at the event as affected by too many tourists (ibid). Amsterdam, it goes without saying, is not the norm and neither is Barcelona. Both cities have seen above-average increases in tourism activity over the past decade (both in terms of arrivals and overnight stays) and record tourist per resident ('tourism intensity') and tourist per square kilometer ('tourism density') ratios that are significantly above the levels recorded in most European cities of their size (Eurostat, 2018; Dredge et al., 2016). In addition, debates about a maximum limit to tourism development are further fueled by the propensity of visitors to concentrate overwhelmingly in the narrow confines of their historic cores. At the same time, however, such developments are certainly not unheard of elsewhere. If the above-mentioned survey is to be believed one in ten of all visitors to cities in 2017 expressed concern about overcrowding (ITB Berlin, 2017) and concerns about excessive demand pressures have especially in smaller heritage cities become increasingly commonplace. The question of how many visitors a given destination can 'carry' and how one can prevent tourism demand from going beyond acceptable limits - it is with regard to urban tourism no longer, as was previously the case, a largely hypothetical one. Instead, understanding what those limits are and how visitation levels that exceed them can be addressed has in a growing number of cities become an increasingly urgent, practical matter and policy makers in several of them are already experimenting with measures to reduce visitation levels at particular times and/or places.

\section{3. $\quad$ Tourism $\neq$ tourism}

Especially against the backdrop of tourism's phenomenal growth within cities the question when it is that enough is enough makes for an interesting research question. It 
should not make us forget, however, that tourists are not a homogeneous lot. That tourists differ widely in terms of their backgrounds, travelling styles, activities, etc. has long been established. In fact, some scholars such as Meethan (2001) have argued that it is more appropriate to speak of tourisms in the plural rather than of tourism as a single category. To some people this may reflect a mere exercise in semantics, however, in order to come to grips with the current controversies surrounding tourism in cities, it is essential to bear in mind that tourism as a social phenomenon is characterised by enormous complexity (Franklin, 2003; Williams and Lew, 2014). This complexity has if anything increased in recent decades as tourism flows have not only grown significantly but also become more and more diverse and variegated in their composition (Robinson and Novelli, 2005; see also Williams and Lew, 2014). This is the case generally, but particularly true for tourism in cities. While the reasons for tourists visiting let's say a sun-and-beach or an alpine destination may to this day be comparatively straightforward and penetrable, the same cannot be said for tourists visiting cities (Maitland and Newman, 2009, p. 3). The latter have throughout history attracted visitors for all sorts of reasons and purposes and are today attracting tourist flows that have been found to be so multifarious and so diverse so as to render any attempt at generalisation or comprehensive listing impossible (see Ashworth 2009, p. 209; see also Ashworth and Page, 2011).

Why is this important? It is important for at least two reasons, the first being rather obvious that different kinds of tourism have different impacts, both positive and negative, on host communities. The second is that many of the current backlashes reported in cities, upon closer inspection, appear to be less directed against tourism in its entirety than against particular types of tourism or tourists. A case in point is the rise of what is variously referred to as "nightlife tourism', 'party tourism', 'get-drunk tourism' or 'alcotourism' (Bell, 2008). It is not a new phenomenon but one that has - not least due to to the rapid expansion of low-cost air travel favouring its growth - become increasingly prevalent and consequential in recent years. And it has played in numerous contexts a central role in debates about urban tourism as a 'problem' requiring greater (policy) attention. Cities in Southern Europe such as Lisbon (Nugent, 2016; Nofre et al., 2018) are obvious examples, as are Central and Eastern European cities such as Cracow, or Budapest (Smith et al., 2017). Decrying an alleged onslaught of 'young, party-mad tourists' on the city's former Jewish quarter and the 'uncivil behaviour' associated with alcohol- 
fuelled nightlife consumption, a journalist of the conservative newspaper Magyar Nemzet recently declared for instance that the situation in Hungary's capital had reached a boiling point, adding 'something needs to be done about it immediately' (László, 2017).

In Hong Kong, another city which has been in the news with reports about 'anti-tourist protests', grassroots mobilizations are meanwhile - as anyone remotely familiar with the city is probably aware of - overwhelmingly concerned with tourists of a particular background. Against the backdrop of broader struggles around the relationship between the People's Republic of China and the Hong Kong Special Administrative Region, it was the steep rise in mainland Chinese visitors, the number of which increased tenfold between 2000 and 2015, that generated contention and hostility among parts of Hong Kong's residents (Garrett, 2016; Rowen, 2016). The heated tensions between locals and mainland visitors, who are often referred to as 'locusts' devouring Hong Kong's resources, serve as a particularly drastic illustration of two more general points that are important to mention with respect to recent contestations surrounding urban tourism. First, they illustrate that the latter walk a dangerously fine line between legitimate protest and parochial and sometimes xenophobic attacks. Secondly, the case of Hong Kong underscores the need to address contestations surrounding urban tourism not in isolation from, but in firm connection with the wider social and political - including, at least in the case of Hong Kong, geopolitical - contexts in which they occur.

\section{Conflict in the 'tourist city' or tourism in 'conflict cities'?}

Tourism is a 'situated phenomenon' (Pasquinelli and Bellini, 2017, p.3) and it has become a generallywidely accepted truism in tourism studies and related fields that local responses to tourism are not only shaped by the kind and extent of tourism development that occurs in a given area but also conditioned by the context in which that development occurs. (Harrill, 2004; Sharpley, 2014; Williams and Lew, 2014). While recognizing the role of context is one thing; however, it is quite another to determine what context(s) to consider or, put differently, where context begins and ends when trying to establish why conflicts and disputes emerge in some places - and fail to occur in others. While this is an important debate, it is not one that can be resolved here. What I would like to do instead is to highlight one important point to consider and 
understanding conflicts and disputes about and around tourism and that is the more general consolidation of diverse forms of urban social mobilization, confrontation, and struggle recent years have been characterised by. Cities have, of course, throughout history been major sites of all sorts of political and social struggles. The strength of these struggles ebbs and flows over time, however, and I think that it is hardly a coincidence that tourism-related conflicts in cities began to garner attention at the same time that critical urban studies diagnosed a more general upsurge of urban conflicts and contestations (Harvey, 2012; Swyngedouw, 2014). Instead, it appears helpful - if not indispensable - to analyse and contextualize the subject matter of 'protest and resistance in the tourist city' against the backdrop of - and as intrinsically connected to wider struggles around contemporary urban restructuring, the direction and consequences of processes of urban change as well as the 'Right to the City' (Novy and Colomb, 2016, p.6). There are several reasons why I believe that this is the case - the most obvious of which being that groups and initiatives contesting tourism in cities are often either not exclusively concerned with tourism, are linked to existing urban social movements and civil society groups (e.g. residents' or neighbourhood associations, housing rights collectives) or at least gained momentum in the slipstream of a more general resurgence of practices of protest, mobilization and resistance in and about urban space. Barcelona illustrates this quite well. It was a more general upsurge in citizens' activism and local urban social mobilization that catapulted the city's current mayor Ada Colau Ballano and her citizen platform Barcelona en Comú (Barcelona in Common) into power in 2015 and both have played important roles in mobilising and coordinating tourism-related collective actions on both the neighbourhood level and citywide (Russo and Scarnato, 2017).

Likewise, in Berlin mobilisations against tourism also are strongly tied to wider struggles, including, perhaps most notably, struggles for affordable housing, against gentrification, and against corporate developments that (are perceived to) destroy the fabric of local communities (Füller and Michel, 2014; Novy, 2016; Novy, 2017). Would tourism have become as contentious as it did in a context other than the present? There is no way of knowing for sure, but it does not seem too far-fetched to suppose that tourism's connection to and imbrication with these broader issues has significantly contributed to the 'growing anti-tourist feeling in the city' (Stallwood, 2012). A closer look at the geographies, or spatialities, of conflicts surrounding tourism within 
the city lends support to this assertion (Novy, 2013). It shows that the latter frequently take place in particular areas - areas that typically find themselves embroiled in other conflicts and tensions over urban space and urban resources, the consequences of neoliberal urban restructuring, as well as the question who dictates the quality and organization of everyday life.

At the same time, there is also evidence that by no means all organised manifestations of protest against tourism can, as hinted at above, be regarded as 'progressive' urban social mobilizations. Tensions surrounding tourism involve different actors with different motives and agendas and can, as has been the case in several neighbourhoods in Istanbul (K1z1ldere \& Günay, 2016; Kadıoğlu Polat, 2016), also be provoked by conservative parochialism (Harvey, 1996) as well as fear and resentment of 'outsiders' who are seen as different and threatening to an existing order. There's some truth to the assertion that tourists are frequently framed and used as scapegoats for all sorts of real and imagined social woes; woes that typically are not primarily - let alone exclusively - owed to tourism (Alas, 2011). Likewise, it is true that conflicts can be motivated by aggression or intolerance towards those that are different (Reisinger and Turner, 2012, p.165) or driven by the NIMBYist desire to 'protect' local amenities from outside intrusion (Murphy and Murphy, 2004, p.21'). Whether and which of these concerns and sentiments actually accompany and inform manifestations of protest and resistance related to tourism is something that needs to be investigated empirically and scholars when doing so must also be open to the possibility that all of them are, to varying degrees, at once at play when conflicts and contestations occur.

\section{5. 'New' conflicts because of 'new' micro-geographies?}

Another important aspect that warrants attention when trying to make sense of the rise of tourism-related conflicts and contestations relates to the 'new culture(s) of urban tourism' this special issue is chiefly concerned with and, along with it, the spatialities of tourism in and across city space. In many cities, urban tourism has not only grown significantly in recent decades in terms of visitor numbers. Rather tourism in cities has also spread geographically across urban space and there is reason to believe that tourism's increasing presence in areas previously not 
visited, or at least less frequented by tourists, has a role to play in its current problematisation and contestation.

Noteworthy is in this context particularly the rise of what Maitland has called 'new tourism areas' (Maitland, 2008, see also 2007, 2010 and Maitland and Newman, 2009). By this, he means areas that were initially largely devoid of 'mainstream' attractions, neither planned nor marketed as tourist zones, and that developed into desirable sites of tourism and place consumption due to a combination of factors of which their supposed distinctiveness and difference from areas homogenized and branded for consumption is one. Examples of "new tourism areas' in Berlin include places like Kreuzberg and Neukölln in former West Berlin and former East Berlin's Prenzlauer Berg or Friedrichshain. Paralleled by similar developments elsewhere, e.g. in East and North London, (Maitland, 2006; Maitland and Newman, 2004; Pappalepore, Maitland and Smith, 2014); Belleville and the area surrounding Canal Saint Martin in Paris (Gravari-Barbas and Jacquot, 2016; Ingallina and Park, 2009), or parts of Brooklyn in New York (Gross, 2008), these former working-class and post-industrial districts at the fringe of Berlin's city centre have since the late 1990s experienced significant increases in tourism activity and are today firmly integrated into the city' tourism trade (see Novy, 2013; Novy 2016). Neither planned nor marketed as tourist zones means by extension that we are dealing here with areas that were not used to, let alone prepared for prepared for increased tourism, and this may well be one of the reasons why we have seen tourism-related conflicts and contestations emerge in many of them.

Again, not all of this is altogether new: the geographical spread across and within urban spaces is not, and neither are conflicts and tensions resulting from it. In fact, the relevant literature is full of references to the penetration of what MacCannell (1976), drawing on the writings of Goffman (1959), described as the 'backstages' of everyday local life as a main cause of conflict and quarrel. But there is an argument to be made that the number of areas affected has expanded and that developments in many of them have intensified. In addition, the potential for conflict is greatly elevated by the fact that tourism development today is, as hinted at above, frequently considered to be closely intertwined with gentrification with the latter serving as cause, context and/or consequence of what today is routinely referred to as 'touristification' (Gravari-Barbas 
and Guinand, 2017). Accordingly, contestations of tourism in cities are in many cities are inextricably linked and tied to urban conflicts over gentrification (Cócola-Gant, 2018). On the one hand, activists raise legitimate concerns about the contribution of tourism to gentrification and displacement - e.g. by fueling the proliferation of vacation rentals which has in recent years emerged as a key 'gentrification battleground' (Cócola Gant, 2016) in numerous cities worldwide. And on the other hand, it seems that tourism has in many contexts emerged as a sort of proxy objection regardless of its actual role in shifts in the socio-economic, physical and symbolic contours of local communities (Füller and Michel, 2014).

What makes much of this ironic, if not tragic, is that tourism's ongoing, and, it seems, accelerating, geographical spread is at least connected to trends in tourism demand that were not too long ago - and, it appears now, prematurely - hailed as hallmarking the advent of a less 'intrusive' and more 'sustainable' era of tourism. What I am alluding to is the alleged shift from 'old', Fordist style mass tourism to an increasingly segmented and flexible 'new tourism' as well as, in particular, the growing demand for 'more real, natural, and authentic experiences' that this shift has been said to be characterised by (Poon, 1989, p. 75; see also Poon, 1994). Changes in tourism demand constitute not the only, but an important pretext for the continuous growth of tourism beyond destinations' conventional sights and sites. They are amplified by rapid technological advances especially in information and communication technologies (ICTs). The latter have greatly enhanced tourists' flexibility and access to information when travelling through space and time (see, i.a., Hannam et al., 2014; Bock, 2015) and dissolved much of the 'information divide' (Bock, 2015, p.14) that traditionally put them at a disadvantage against locals when searching for information about experiences offside the 'beaten tracks'. Add to this the rise of home-sharing platforms like Airbnb which have vastly expanded accommodation opportunities to choose from (Guttentag, 2015; Dredge et al., 2016; Cócola Gant, 2016), and it becomes clear that today's travellers are in many ways better equipped to escape officially sanctioned tourist sites and immerse themselves in the places they are visiting than previous generations. What they cannot escape from is the well-rehearsed charge famously expressed by Hans Magnus Enzensberger (1996 [1958]) that 'the tourist destroys what he seeks by finding it' which appeared on dozens of anonymously pinned up posters in Berlin in the summer of 2010. Rather, their desire to transcend the areas primarily dedicated to, or taken over by tourism, is today 
regularly highlighted as part of the 'problem'. As one resident, complaining about the impact of the proliferation of short-term rentals and evoking Airbnb's slogan 'live like a local,' remarked at a public event about tourism in Amsterdam in 2016: '[if we don't put a stop to this,] there will be no locals left that tourists can pretend to live like.'

\section{Complicating matters: the question 'who is a tourist?'}

Disputes about the proliferation of short-term rentals have in recent years emerged as one of the most contentious aspects in the wider debate around the impacts of tourism on cities and neighbourhoods within them. Claiming that $74 \%$ of its rentals are outside destinations' 'main hotel districts', Airbnb commends itself for 'democratizing tourism [by] giving millions of everyday people the chance to travel to cities and neighborhoods they might otherwise miss, and disproportionately bringing economic benefits to communities that typically have not benefited from tourism' (Airbnb, 2016, p.1). Critics meanwhile assert that such claims fail to consider crucial issues of community power and accuse Airbnb of exacerbating housing shortages, fueling gentrification and being a key force behind the 'expansion of central city tourist bubbles' (Ioannides et al., 2018, p. 7).

At the same time, however, it is worth noting that the rise in popularity of sharing or platform economy companies such as Airbnb has occurred at a time in which a growing number of scholars are also raising questions about who tourists actually are and what tourism entails. Users of Airbnb and similar services are in popular and media discourses routinely portrayed as tourists and the rise of platforms like Airbnb routinely discussed with reference to tourism. But demand for short-term rentals is diverse, certainly more diverse than the term 'vacation-rentals' that is frequently employed suggests, and this diversity if anything underlines the need to critically reflect on the notion of tourism itself and the role the latter plays in processes of urban change.

Drawing clear-cut distinctions between touristic and non-touristic activities has never been easy but has become much more difficult (some might say impossible) in recent years due to the changing and increasingly complex realities that have come to characterise tourism and contemporary cities. The latter involve, as mentioned before, not only a growth in tourism mobility but also a multiplication of tourism-related practices. Many visitors stay longer or 
shorter than conventional wisdom about urban tourism has it; come with expectations and demands that have only little to do with what tourists according to common storylines are supposed to expect and want and differ in their choice of activities and experiences from what established notions of tourist behaviour suggest. Frequent visitors or those travelling to visit friends or relatives are cases in point and conventional understandings of tourism are moreover challenged by the growing presence and prevalence of other 'temporary city users' (Costa and Martinotti, 2003): so-called 'digital' or 'global' nomads who live and work locationindependently (Makimoto and Manners, 1997; Kannisto, 2016), artists in residence, academics on sabbaticals second homers, or students on exchange to name but a few. Neither readily identified as 'tourists' nor as permanent 'residents', these groups illustrate the difficulties involved in drawing a clear line between tourism and other forms of mobility on the one hand as well as tourism and everyday life on the other hand particularly well. In fact, while tourism has typically been associated with rather limited periods of movement or displacement, growing numbers of commentators now recognise that defining clear lines between (more) temporary and (more) permanent moves is becoming increasingly untenable and that tourism instead forms part of a 'continuum of mobilities' along which roles and outlooks overlap and intertwine (see Bell and Ward, 2000, p.88; Williams and Hall, 2002).

What complicates matters further is what Franklin referred to as the 'touristification of everyday life' (2003, p. 206). Especially middle- and upper-class urban dwellers have been found to increasingly display attitudes and behavioural patterns that are hard to distinguish - and sometimes indistinguishable - from those of visitors. They act 'as if tourists' (Lloyd and Clark, 2001, p. 357; see also Clark, Lloyd, Wong, and Jain, 2003) when exploring and consuming urban neighbourhoods in the cities they reside in. And they have been found to use urban spaces and resources in ways that are not radically different from those of visitors when going after their daily lives in their own communities.

Scholars in tourism sociology and related fields such as Urry (1990, 1995, 2007) or Munt (1994) have long argued that the broader processes of societal change that have in recent decades greatly elevated tourism's influence as a social force paradoxically also call the very notion of tourism as a distinct social phenomenon into question. They argue that tourism has become so 
complex and so pervasive that it has lost its 'specificity' (Urry, 1990, p. 82), point to a progressive blurring of boundaries between tourism and daily life, and along with it challenge many related binaries such as the traditional distinctions between home and away, the ordinary and the extraordinary, or 'hosts' and 'guests' on which tourism has traditionally been defined and theorised (Johannesson et al., 2015). Whether or not it makes sense to talk about an 'end of tourism' (Urry, 1995, p. 147) and whether we really live in a world in which 'tourism is everything and everything is tourism' (1994, p. 104) is certainly a matter of debate. Two things are clear, however. The first is that there is a debate to be had about who we are talking about and who we are not talking about - when the ramifications of tourism - or what is perceived as tourism - are explored and discussed. And secondly, caution should be exercised with regard to the dichotomised 'tourist' versus 'local' distinction that conversations about conflicts and controversies surrounding urban tourism in one way or the other are more often than not are premised upon. By this, I don't mean that such a distinction has become altogether meaningless in all circumstances and cases. Rather it is the taken-for-grantedness with which conflicts pertaining to tourism are portrayed as ones between tourists and locals that ought to be problematized and questioned. In many contexts - such as those involving 'new tourism (areas)' - conflicts appear to be infinitely more complex than the classical storylines that pit tourists against locals imply.

\section{Conclusions}

Across the globe, from established tourist cities such as Venice or Prague to less traditional tourist destinations in both the global North and South, there is mounting evidence pointing to a proliferation of conflicts and contestations surrounding urban tourism. These conflicts and contestations have received considerable attention in recent years, especially by the media, and have put the spotlight on the discontents of tourism in cities. This is a welcome development, especially in light of the uncritical boosterism that until recently dominated headlines and policy debates and effectively deflected, or suppressed, concerns about the challenges and downsides tourism can create. It is important, however, not to go from one extreme to the other. Manifestations of protest and resistance in tourist cities are still rather the exception than the rule and especially in light of the at times sensationalist and simplistic tourist 
bashing recent controversies have given rise to in some quarters one ought to be careful to keep things in perspective. This means, as Cohen put it already more than thirty years ago, to avoid both extremes: that of a 'total condemnation of tourism as well as [that] of its uncritical approbation' (Cohen, 1988, p. 384). The main aim of this commentary has been to provide some thoughts and insights into the causes and characteristics of tourism's increasing problematisation and politicisation in cities. I have

- emphasised the obvious but sometimes not sufficiently appreciated fact that contestations in several cities need to be made sense of against the backdrop of massive and often rapid increases in tourism activity in those places but that backlashes at the same time are often less directed against tourism in its entirety than against particular kinds of tourism (or tourists);

- stressed the need to account for the context in which tourism occurs and contestations emerge, involving, in particular, the more general rise of struggles and protests in and about urban space;

- hypothesized that the spatial expansion of tourism within and across urban space and especially the emergence of so-called 'new tourism areas' may help in many contexts to explain the proliferation of conflicts and contestations; and

- highlighted the importance to critically engage with the notion of tourism itself to move beyond essentialising, misrepresenting, and 'othering' narratives that position tourists and locals as binary opposites and treat tourism as an altogether distinct, easily separable social phenomenon.

Tourism's current problematisation and politicisation in cities constitutes a research frontier with a wide-open landscape to explore and it goes without saying that the issues this commentary has focused on are not the only ones worthy of attention. But they hopefully will provide orientation and inspiration as we try to make better sense of the rise of urban tourism as a source of discontent and dispute. Doing so will require further in-depth single case and comparative analyses concerning cities and places within them in which tourism-related conflicts in cities can be observed, but, crucially, would also benefit from more engagement with heavily visited urban environments in which these conflicts are absent or at least appear significantly less pronounced. In addition, there remains ample room for methodological and theoretical advances in the interest 
of refining our understanding of the issues under discussion. This involves, amongst other things, the challenges the above-discussed interconnectedness of different expressions of mobility and place consumption involves for conceptualising and, indeed, operationalising tourism for analytical as well as particularly planning and policy purposes (Novy, 2017). And it involves, related to this, the need to rethink established frameworks to 'measure' - and respond to - what is perceived as tourism-induced urban change.

\section{Bibliography}

Airbnb (2016), “Airbnb Policy Tool Chest” (Industry report). San Francisco, SA: Airbnb. Available at https://www.airbnbcitizen.com/wp-content/uploads/2016/ (accessed 22 April 2018)

Ajuntament de Barcelona (2017), "Pla Estratègic de Turisme 2020: Programes d'actuació". Available at https://ajuntament.barcelona.cat/turisme/sites/default/files/documents/170126_pet20_programes (accessed 22 April 2018)

Alas, J. ( 2011), "Stop blaming 'party tourists" for Berlin's problems", Der Tagesspiegel, 9 March, available at http://www.tagesspiegel.de/weltspiegel/in-english/ racismand-xenophobiastop-blaming-party-tourists-for-berlins-problems/ 3930536.html (accessed 22 April 2018)

Ashworth, G.J. (2009), "Questioning the Urban in Urban Tourism", in Maciocco, G. and Serreli, S. (Eds), Enhancing the City. New Perspectives for Tourism and Leisure. Dordrecht/New York: Springer, pp. 207-220

Ashworth, G., and Page, S. J. (2011), "Urban tourism research: Recent progress and current paradoxes". Tourism management, 32(1), pp. 1-15

Becker, E. (2015), “The revolt against tourism”, New York Times, 17 July, available at https://www.nytimes.com/2015/07/19/opinion/sunday/the-revolt-against-tourism.html (accessed 12 December 2017).

Bell, M., and Ward, G. (2000), “Comparing temporary mobility with permanent migration”, Tourism Geographies 2(1), pp.87-107.

Bell, D. (2008), “Destination drinking: Toward a research agenda on alcotourism”. Drugs: education, prevention and policy. 15(3), pp.291-304

Boissevain, J., (1996), "Introduction”, in Boissevain, J (Ed) Coping with tourists: European reactions to mass tourism, Oxford: Berghahn, pp.1-26

Clark, T., Lloyd, R., Wong, K. K., and Jain, P. (2003), “Amenities drive urban growth: a new 
paradigm and policy linkages", in Clark, T. (Ed) The City as an Entertainment Machine.

London: Emerald, pp. 291-322

Cócola-Gant, A. C. (2016), "Holiday rentals: The new gentrification battlefront", Sociological Research Online, 21(3)

Cócola-Gant, A (2018), “Tourism gentrification“, in Lees, L and Phillips, M (Eds) Handbook of Gentrification Studies. Cheltenham and Northampton: Edward Elgar Publishing.

Cohen, E. (1988), “Authenticity and commoditization in tourism”, Annals of tourism research, 15(3), pp. 371-386.

Coldwell, W. (2017), "First Venice and Barcelona: now anti-tourism marches spread across Europe", The Guardian, August 10, available at https://www.theguardian.com/travel/2017/aug/10/anti-tourism-marches-spread-across-europevenice-barcelona (accessed 12 December 2017).

Costa, N. and Martinotti, G. (2003), "Sociological theories of tourism and regulation theory", in Hoffman, L., Fainstein, S. and Judd, D (Eds), Cities and Visitors: Regulating People, Markets, and City Space. Oxford and New York: Blackwell, pp.53-72.

Devaney, B. (2015), "This is why Amsterdam, Barcelona, and Venice are all trying to clamp down on tourists", City Metric, November 23, available at https://www.citymetric.com/business/why-amsterdam-barcelona-and-venice-are-all-tryingclamp-down-tourists-1617 (accessed 12 December 2017).

Dredge, D., Gyimothy, S., Birkbak, A., Jensen, T.E., Madsen, A.K. (2016), “The impact of regulatory approaches targeting collaborative economy in the tourism accommodation sector: Barcelona, Berlin, Amsterdam and Paris.” Impulse Paper No.9. Brussels: European Commission

Enzensberger, H. M. (1996), “A theory of tourism”, New German Critique, 68, pp.117-35.

Eurostats (2018), "Culture and tourism - cities and greater cities", available at http://ec.europa.eu/eurostat/web/products-datasets/-/urb_ctour (accessed 12 April 2018).

Franklin, A. (2003), “Tourism. An Introduction”. London: Sage

Füller, H. and B. Michel (2014), "Stop Being a Tourist!' New dynamics of urban tourism in Berlin-Kreuzberg”. International Journal of Urban and Regional Research, 38, pp. 1304-1318

Garrett D (2016), “Contesting China's tourism wave. Identity politics, protest, and the rise of the Hong Kong city-state movement", in Colomb C. and Novy J. (Eds) Protest and Resistance in the Tourigkonst City. London: Routledge, pp. 107-128

Goffman, E. (1959), The Presentation of Self in Everday Life. Harmondsworth: Penguin. 
Goodwin, H. (2017). The Challenge of Overtourism. Responsible Tourism Partnership Working Paper 4

Gravari-Barbas, M. and Jacquot, S. (2016), "No conflict? Discourses and management of tourism-related tensions in Paris", in Colomb, C. and Novy, J. Protest and Resistance in the Tourist City, London and New York: Routledge, pp. 31-51

Gravari-Barbas, M., and Guinand, S. (2017), Tourism and Gentrification in Contemporary Metropolises. International Perspectives. London and New York: Routledge

Gross, J. (2008), “New York tourism: dual markets, dual agendas”, in: Maitland, R. and Newman, N. (Eds), World tourism cities. London: Routledge, pp.87.108

Guttentag D (2015), “Airbnb: disruptive innovation and the rise of an informal tourism accommodation sector", Current issues in Tourism 18(12), pp. 1192-1217.

Harrill, R. (2004), "Residents' attitudes toward tourism development: A literature review with implications for tourism planning”, Journal of planning literature, 18(3), pp.251-266

Harvey, D. (1996), Nature, Justice and the Geography of Difference. Malden, MA: Blackwell.

Harvey, D. (2012), Rebel cities. London: Verso Books

Ingallina, P. and Park, J. (2009), "Tourists urban projects and spaces of consumption in Paris and Ile-de- France", in Maitland, R. and P. Newman (Eds), World tourism cities. Developing tourism off the beaten track. Abingdon: Routledge, pp. 43-65

Ioannides, D., Röslmaier, M., and van der Zee, E. (2018), “Airbnb as an instigator of 'tourism bubble' expansion in Utrecht's Lombok neighbourhood”, Tourism Geographies, pp.1-19.

IPK International (2016), “ITB world travel trends report 2015-6”, Messe Berlin GmbH, Berlin.

ITB Berlin (2017), "25th World Travel Monitor Forum in Pisa: International travel industry needs new strategies to manage 'overtourism"', Press release, December 14, available at https://www.itb-berlin.com/Press/PressReleases/News_49298.html (accessed 12 January 2017)

Jóhannesson, G.T., C.B. Ren and van der Duim, R. (2015), “Tourism encounters, controversies and ontologies", in Jóhanesson, G.T., Ren, C.B. and van der Duim, R. (Eds), Tourism encounters and controversies: ontological politics in tourism development. Aldershot: Ashgate, pp. 81-107

Kadığlu Polat, Defne (2016), “'There is nothing quite like Tophane'. A case study of gentrification in Istanbul", Istanbul, IPC

Kannisto, P. (2016), Global nomads and extreme mobilities. Aldershot: Ashgate 
Kizıldere, D., and Günay, Z. (2016), "Hate gentrification, love the gentrifier: conservative resistance in Tophane". Paper presented at the RC21 Annual Conference, Mexico City, Mexico, July 2016, available at http://rc21- mexico16.colmex.mx/images/abstracts/stream19/stream19panel1-kizildere.pdf (accessed 12 May 2018)

László, C. (2017), “A turista nem közellenség”, Magyar Nemzet, August 15, available at https://mno.hu/velemeny/a-turista-nem-kozellenseg-2412581 (accessed 12 December 2017).

Lloyd R. and Clark, T.N. (2001), "The city as an entertainment machine", in Gotham, K.F. (Ed) Critical Perspectives on Urban Redevelopment. Elsevier Science, Amsterdam, pp. 357 - 378

MacCannell, D. (1976), The tourist: A new theory of the leisure class. California: University of California Press

Maitland, R. (2007), "Tourists, the creative class and distinctive areas in major cities: the roles of visitors and residents in developing new tourist areas", in Richards, G. and Wilson, J. (Eds) Tourism, Creativity and Development, London: Routledge, pp. 73-86.

Maitland, R. (2010), "Everyday life as a creative experience in cities". International Journal of Culture, Tourism and Hospitality Research, 4, pp. 176-185

Maitland, R., and Newman, P. (2009), "Developing world tourism cities", in Maitland, R. and P. Newman (Eds), World Tourism Cities: Developing Tourism Off the Beaten Track. London: Routledge, pp. 1-21.

Makimoto, T. and Manners, D. (1997): Digital Nomad. Chichester: Wiley.

Meethan, K. (2001), Tourism in global society: Place, culture, consumption. New York: Palgrave.

Munt, I. (1994), “The 'other' postmodern tourism: culture, travel and the new middle class". Theory, Culture and Society 11, pp. 101-123.

Murphy, P. E., and Murphy, A. E. (2004), Strategic management for tourism communities: Bridging the gaps. Channel View Publications

Nofre, J., Martins, J. C., Vaz, D., Fina, R., Sequera, J., and Vale, P. (2018), “The 'Pink Street'in Cais do Sodré: urban change and liminal governance in a nightlife district of Lisbon". Urban Research and Practice, pp. 1-19.

Novy, J. (2013) “'Berlin does not love you': notes on Berlin's 'tourism controversy' and its discontents", in M. Bernt, B. Grell and A. Holm (Eds), The Berlin Reader: A Compendium on Urban Change and Activism Bielefeld: Transcript, pp. 223-237.

Novy, J. (2016), "The selling (out) of Berlin and the de- and re-politicization of urban tourism in Europe's 'Capital of Cool'”. In Colomb, C. and Novy, J. (Eds), Protest and Resistance in the 
Tourist City. London: Routledge, pp.52-72

Novy, J. (2017), “'Destination'Berlin revisited. From (new) tourism towards a pentagon of mobility and place consumption". Tourism Geographies, pp. 1-25

Novy, J., and Colomb, C. (2016), "Urban tourism and its discontents: an introduction", in Colomb, C. and Novy, J. (Eds). Protest and resistance in the tourist city. London: Routledge, pp. $1-30$

Nugent, C. (2016) "Lisbon is a city famed for its nightlife - and the residents hate it", City Metric. October 6, available at: www.citymetric.com/business/lisbon-city-famed-its-nightlifeand-residents-hate-it-2478 (accessed 12 December 2017).

Pappalepore, I., Maitland, R., and Smith, A. (2014), "Prosuming creative urban areas. Evidence from East London", Annals of Tourism Research, 44, pp. 227-240.

Pasquinelli, C., and Bellini, N. (2017), "Global Context, Policies and Practices in Urban Tourism: An Introduction", in Bellini, N and Pasquinelli, C. (Eds).Tourism in the City. Dordrecht/New York: Springer, pp. 1-25

Pinkster, F. M., and Boterman, W. R. (2017), "When the spell is broken: gentrification, urban tourism and privileged discontent in the Amsterdam canal district". Cultural Geographies, 24(3), pp. $457-472$

Poon, A. (1989), "Competitive strategies for a 'new tourism"', in Cooper, C.P. (Ed), Progress in Tourism, Recreation and Hospitality Management. London: Belhaven Press, pp. 91-102

Poon, A. (1994), "The 'new tourism' revolution”. Tourism Management 15(2), pp. 91-92.

Reisinger, Y., and Turner, L. (2012), Cross-cultural behaviour in tourism. London: Routledge.

Robinson, M., and Novelli, M. (2005), "Niche tourism: An introduction", in Novelli, M (Ed), Niche tourism: Contemporary issues, trends and cases. Oxford: Elsevier, pp. 1-11

Rowen, I. (2016), "The geopolitics of tourism: Mobilities, territory, and protest in China, Taiwan, and Hong Kong". Annals of the American Association of Geographers, 106(2), pp.385393

Russo, A.P. (2002), “The 'vicious circle' of tourism development in heritage destinations", Annals of Tourism Research, 29(1), pp. 165-82.

Russo, A. P., and Scarnato, A. (2017), “'Barcelona in common': A new urban regime for the 21st-century tourist city?", Journal of Urban Affairs, pp. 1-20.

Sharpley, R. (2014), "Host perceptions of tourism: A review of the research", Tourism Management, 42, pp. 37-49. 
Sheivachman, A. (2017), "Summer of Overtourism: 4 Lessons for the Travel Industry", Skift, August 16, available at https://skift.com/2017/08/16/summer-of-overtourism-4-lessons-for-thetravel-industry/.

Slegers, M. (2017), "Amsterdam attempts to stem its tourist flood and regain its soul", Politico, 20 January, available at www.politico.eu/article/amsterdam-tourism-airbnb-crime-netherlands/.

Stallwood, O. (2012), "How Berlin is fighting back against growing anti-tourist feeling in the city", The Guardian, December 4, available at https://www.theguardian.com/travel/2012/dec/04/berlin-fights-anti-hipster-tourism-abuse (accessed 12 December 2017.

Swyngedouw, E. (2014), "Insurgent architects, radical cities and the promise of the political", in Swyngedouw, E. and J. Wilson (Eds) The Post-Political and Its Discontents: Spaces of Depoliticization, Spectres of Radical Politics. Edinburgh: Edinburgh University Press, 2015), pp. 169-87.

TourMIS. (2017). City tourism in Europe. Retrieved from http://www.tourmis.info.

UN World Tourism Organization [UNWTO] (2012), "Global Report on City Tourism”, available at http://affiliatemembers.unwto.org/publication/global-report-city-tourism (accessed 12 December 2017.

Urry, J. (1990), The Tourist Gaze. London: Sage Publication

Urry, J. (1995), Consuming places. London: Sage Publication

Urry J. (2007), Mobilities. Cambridge: Polity

Williams, A. M. and Hall, C. M. (2002), Tourism and migration. Dordrecht/New York: Springer

Williams, S., and Lew, A. A. (2014), Tourism geography: Critical understandings of place, space and experience. London: Routledge 